УДК 141(37-11+4-15)"2/13"

DOI 10.35423/2078-8142.2021.2.1.7

В. Д. Білодіо,

кандидат філософських наук, старший науковий співробітник відділу історії філософії Украӥни Інституту філософії імені Г. С. Сковороди НАН Украӥни,

м. Київ, Украӥна

e-mail: bilodid.vd@gmail.com

ORCID: https//orcid.org/0000-0003-3097-962X

\title{
ПЛАТОНІЗМ ТА АРІСТОТЕЛІЗМ ЯК ДЖЕРЕЛО ВІДМІННОСТЕЙ ВНУТРІШНЬОЇ ФОРМИ ХРИСТИЯНСЬКИХ ТРАДИЦЙ ЗАХІДНОЇ ЄВРОПИ ТА ВІЗАНТІї ДОБИ СЕРЕДНЬОВІЧЧЯ
}

У статті досліджуються особливості ставлення в Західній Європі та Візантії до грецької філософії в контексті історичного розгортання полярності ментальностей $і$ культур античної Греції та Давнього Риму, з одного боку, та філософських вчень Платона/Плотіна й Арістотеля - з іншого. Показано, щзо иі полярності в перетворених формах проявилися в розділенні середньовічної Свропи на християнський Схід (грекомовну та «грекодумаючу» Візантію) як прямого спадкоємия грецької культури, $і$ на християнський Захід, як прямого спадкоємия латинської культури. Засвоєння тут i там християнства крізь «фільтри» різних ментальностей $i$ культур, у взаємодії з іншими історичними чинниками, спричинило розділення християнства на православ'я («грещьку» Церкву) і на католицизм («латинську» Церкву). Стверджується думка про те, що латинська патристика органічно переросла на Заході в домінацію схоластики, чого не було на християнському Сході, де ї̈ повноцінне формування було заблоковано, $i$ де вона залишилася в «пелюшках», у стані протосхоластики. Обстоюється правдивість тези про те, щзо римо-католицький Захід доби схоластики (IX-XIV cm.), спираючись і на платонізм, $і$ на арістотелізм, успадковує як парадигмальний для своєї теології та філософї епістемноарістотелівський тип філософування, а православний Схід, за всіх своїх коливань, продовжує як парадигмальну для своєї духовної ку-

(ㄷ Білодід В. Д., 2021 
льтури, панівну в античності, платонівську лінію філософування. Через Арістотеля, як «батька» схоластики, ї̈ Першофілософа, відбувається інтенсивне «вростання» християнського арістотелізму в культуру західноєвропейціів $і$ їх ментальність, перетворення арістотелізму на «внутрішню форму західної цивілізації» (С. Аверинцеев).

Ключові слова: Візантія, платонізм, арістотелізм, схоластика, софійне філософування, епістемне філософування, православ'я, католицизм.

Автор статті не візантолог і не патролог, а філософ-україніст, який, спираючись на їх напрацювання та власні дослідження постає в даному випадку в ролі 1) почасти збирача думок та концепцій фахівців названого профілю і 2) підсумовувача висновків, що напрошуються зі зведення докупи тих думок та концепцій заради цілком певної мети - 3'ясування особливостей передусім візантійського синтезу християнства і філософії та вибору філософської традиції, яка більшою мірою, ніж будь-яка інша, запліднила духовну спадщину Візантії. Ці питання завжди були злободенними для неї: «проблема співвіднесеності між філософією та істинами християнського досвіду залишалися осереддям богословської ( $i$ фiлософscкої. - В. Б.) думки Візантії», - відзначає І. Мейєндорф, але «якоїсь надійної рівноваги між ними відшукати ще не вдалось» [29, с. 38].

Однак, усе пов'язане з усім. Середньовічна Європа була спочатку єдиною, потім розділилася, а згодом знов поновила тісні зв'язки між християнським Сходом і християнським Заходом. Тому вивчати візантійську духовність доцільно з урахуванням своєрідності духовно-інтелектуальної культури Заходу. Вони подібні, але й дуже різні. Тому бачення однієї з них на тлі іншої дає можливість глибше і повніше зрозуміти кожну 3 них.

Стаття є, наскільки нам відомо, першим в Україні окремим, тематично сфокусованим і більш-менш концептуально-системним дослідженням проблеми співвідношення платонізму та арістотелізму в богословсько-філософській думці Візантії та середньовічної Західної Європи. Хоча, звичайно, кожен, хто писав про цю думку, 
не міг - так чи інакше, побічно або детальніше, - не торкнутися цієї проблеми.

У неозорій за кількістю публікацій візантології та західній мідієвістиці ми спирався передусім на праці О. Лосєва, С. Аверінцева, І. Меєндорфа, Л. Карсавіна, П. Лемерля, Ж. Л. Гоффа, С. Сорочана, О. Каждана, Ю. Чорноморця та ін. Особливо цінними стали публікація О. Койре про арістотелізм та платонізм у латинській схоластиці [див.: 20] і оригінальне бачення Г. Майоровим філософії, основних типів філософування та їх поширення на православному Сході і католицькій Свропі [див.: 27].

Це перша стаття, тобто частина цілого. Тільки разом 3 другою вони утворюють самодостатнє ціле.

Візантія - це унікально життєздатна імперія і перша християнська держава у світі, міст між Сходом і Заходом, а в часі - між Античністю і Ренесансом (та Новим часом) [див.: 36, с. 8], найголовніший (принаймні до підступного захоплення хрестоносцями Константинополя і латинської окупації 1204 р.) цивілізаційнокультурний центр тодішньої ойкумени, оборонно-жертовний мур Західної Європи, що захистив іiї від експансії войовничих ісламських народів. 29 травня 1453 р. Візантія покинула арену історії. Але залишилася «Візантія після Візантії» (Н. Йорга).

Україні, вважає Андрій Окара, варто було б «перевідкрити Візантію», грунтовніше вивчити цивілізаційно-культурний спадок цієї «іншої Свропи», як моделі для осягнення власної ідентичності в іiі спорідненості з ідентичностями давньоруської держави та Великого князівства Литовського [32, с. 187]

Значущість Візантії для України - поза сумнівом. У Середньовіччі вона постала як дарувальниця нашої православної віри i «мати Української церкви» (митроп. І. Огієнко). Сім віків (9881686) церква України-Русі перебувала під юрисдикцією Константинопольського патріархату і понад 250 років Русь входила в «Візантійську Співдружність держав» (Д. Оболенський), які через Візантію «дихали повітрям світової культури» [36, с. 24]. Насамперед від Візантії (та країн названої Співдружності) наші предки отримали парадигмальні засади своєї середньовічної культури, початки науки і філософії, допомогу у створенні писемності, архітектури, 
іконографії, державного адміністрування тощо. За I. Мейєндорфом, «ніщо в їі (Русі. - В. Б.) середньовічній історії та культурі не може бути повною мірою пояснено без звернення до візантійської спадщини» [30, с. 661]. I це робиться. Не так масштабно, як хотілося б, але, загалом, все ж прогресуючи. Бо ще десять років тому, за оцінкою Наталі Яковенко, української візантології, за винятком окремих паростків (у Харкові, Одесі), просто не існувало [див.: 31]. Нині ситуація поліпшується, зокрема і в Києві. Міцнішає усвідомлення, що, вивчаючи візантійську спадщину, ми тим самим вивчаємо праджерела власної духовності, бо ключі до неї приховані не лише всередині країни, а й поза нею. Пошукаємо їх.

Візантія, будучи, з одного боку, причиною (суб'єктом опричинення), в іншому є наслідком дії певних історичних детермінацій. Оминаючи їх, зупинимось на одній, а саме - тій, що пов'язана з розділенням Європи. Бо поява Візантії - це поворотна, не усвідомлювана сучасниками, подія в цьому розділенні. Розділенні, зародки якого ховаються в Античності. Їх треба бачити і враховувати, як це робить Г. Майоров, щоб усебічніше осягнути коріння досліджуваної нами проблеми.

Підмуркові підвалини Західної цивілізації закладені, як відомо, в античній Греції та античному Римі. Менш відомо, що разюча відмінність їх ментальностей і культур - це, може, перші передвісники майбутніх контрастів між європейським Заходом і європейським Сходом. Очевидна сьогодні «антитеза Схід-Захід, - пише Г. Майоров, - первісно відносилася до двох історичних народів, що вийшли на історичну арену: греків та римлян», які за численними античними свідченнями «добре розуміли несхожість і навіть протилежність своїх менталітетів» [27, с. 120]

Греки, зауважує дослідник, відзначалися виключним розвитком уяви, а римляни - прагматичного розсудка; для тих прикметна єдність 3 природою, для цих - заглиблення в «стихію історії та громадського життя»; елліни - вроджені теоретики, римляни - невиправні практики; ті - споглядачі першооснов, вічного, ці - заангажовані часовим, раціоналізацією побуту, пошуком зручностей для приємності земного життя; греки - це першовідкривачі, римля- 
ни - талановиті наслідувачі та продовжувачі; елліни - народ поетів і філософів, римляни - творці юриспруденції, майстри військової справи [див.: 27, с. 125-126]. Вони, зрештою, завоювали Грецію, але в основному політично, культурно вони були завойовані греками. Вони - вчителі римлян майже в усьому, зокрема у філософії. Тут переваги еллінів били очевидні. За кількістю визначних філософів Греція не знає собі рівних, а з Риму попали в підручники хіба що чотири імені: Ціцерона, Сенеки, Лукреція Кара та імператорастоїка Марка Аврелія (знаково, що перші три закінчили життя самогубством, а четвертий був втіленням мужності й розчарування). Грецький філософський розум - умоглядно-спекулятивний, а римський - просвітницько-моралізуючий. У римлян, пише О. Лосєв, була алергія на «небезпечну» пристрасть греків до витонченого теоретизування. «Майже офіційною доктриною римської держави був (запозичений у греків. - В. Б.) стоїцизм» [25, с. 188].

Як греки, які «винайшли» філософію, розуміли те, що вони відкрили? Якими були найголовніші типи еллінського філософування? Одним з останніх перспективно-концептуальне бачення відповідей на ці запитання запропонував Г. Майоров.

Він нагадує, що, за дослідженнями В. Н Топорова, ідея мудрості та відповідний вербальний корелят задокументовані в культурах усіх давніх народів, а от «ідея філософії зустрічається тільки у греків» [27, с. 35] і не має автохтонного відповідника в мовах інших народів давнини. Греція - вічна вітчизна філософії та всіх істинних філософів.

Першим, хто назвав «філософію філософією», а себе філософом, був, за Гераклідом Понтійським, Піфагор [12, с. 66]. Греція приймала його за когось більшого, ніж людина. «Божественною людиною» величає його М. Еліаде [41, с. 220]. За своїм впливом на сучасників і на нащадків, на європейську культуру Піфагор успішно суперничає із Сократом і Платоном [див.: 16, с. 8]. «Батько філософії» гармонійно поєднував у собі вченого, релігійного та морального реформатора і містика-чудотворця («пророка Аполона» [17, с. 14]). Будучи уособленням внутрішньої цільності, Піфагор заклав основи «цілісного знання» - функціонально-екзистенціального, гносеологічного і сотеріологічного водночас 
[див.: 42, с. 222], яке, очевидно, і вважав, власне, філософією. Через духовний синтез містеріального, логічного і морального Піфагор, як відзначає Г. Майоров, створив «новий різновид духовної активності людини - філософську творчість, новий тип людей - філософів і новий спосіб життя - філософський» [27, с. 163]. Належачи до великих боголюбців, Піфагор розумів філософію як теоцентричну форму духовно-когнітивного потенціалу людини. За Ямвліхом Халкідським, який спирався на втрачені для нас біографії Піфагора, «смисл піфагорійської філософії» і «мета, якій підпоряд-

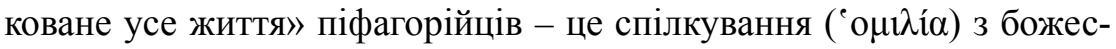
твом» [38, с. 493]. «Слідуй богу», - закликає Піфагор. Він, та його наступники, виходять 3 того, що є боги (Бог) і є люди, які - «власність богів» [Федон, 62b; цит. за: 33]; боги мудрі, а люди покликані шукати цю мудрість, щоб уподібнитися богам. Філософія розумілася як теорія і практика богоуподібнення. «Сократ і Платон, так само, як і Піфагор, - повідомляє Стобей, - вбачають найвищу моральну мету (телос) в уподібненні богові» [38, с. 148], у переході, як пише Платон, у «рід богів», що, застерігає він, «не дозволяється нікому, хто не був філософом» (Федон. 82с.).

Греки, за Г. Майоровим, «не лише відкрили філософію», а й «вичерпали всі можливі способи іiі розуміння» [27, с. 36]. Їх три: софійний (від грец. Бофí - мудрість), епістемний (від єлıбтү́ точно встановлене знання, наука), і змішаний. Основоположниками софійного типу філософування історик вважає Піфагора, Сократа i Платона, родоначальником епістемного - насамперед, Арістотеля, а найвиразнішим представниками змішаного - софістів.

Парадигмальними уособленнями двох найголовніших ліній в історії європейської (і не тільки) філософії стали Платон і його найталановитіший, але й найамбітніший учень - Арістотель. Започаткувавши свою філософську альтернативу вчителеві, Стагірит «полемізує з Платоном та іншими платоніками майже в усіх найбільш істотних питаннях» [40, с. 182].

Платон - це бого- і душе-центрист. Платонова людина - це душа. Вона - «візник», тіло - «колісниця», засіб, але й «в’язниця», що обмежує свободу й злет крилатої душі. Істина - це Бог, вона, як 
і він, захована в глибинах душі. Пізнати істину (і Бога) можна лише через самопізнання. Сакральний заклик пророчиць Дельфійського храму і чи не найголовніше гасло всієї софійно-філософської традиції тотожні: «Пізнай себе!». Тому іiі батьки - це інтелектуальні й духовно-інтуїтивні «провидці» [див.: 41, с. 19], що прислухаються до того, що піднімається із середини й вдивляється в умоглядні реальності. Платон - основоположник європейського ідеалізму і родоначальник європейського містицизму. У візіях «божественного Платона» (чи не єдиного, кого греки визнали таким ще за його життя), земний світ $є$ частиною більшого цілого, визначальним складником якого $є$ світ вічних ідей, парадигмальних констант, моделей плинного світу речей.

Арістотель переінакшує вчення Платона на свій лад. Людина - це не душа в тілі, а єдність душі та тіла [див.: О душе, II 1, 413a 1-5; за виданням: 7]; це розумна смертна тварина. Окремий світ ідей - вигадка. Наш матеріальний світ - це світ єдності форми (арістотелівський аналог ідей) і матерії. Арістотель наполягає на іманентності форм самим речам вічного матеріального світу [див. 39, с. 181]. Істинно сутнісним Платона $є$ ідеальні прообрази речей, а Арістотеля - те незмінне й стале «в самій речі, що робить ії самостійною і є основою іiі буття» [10, с. 159]. Воно, звичайно, «від бога, але вже не богове» [21, с. 64]. І це все змінює. Посутньо ці філософи усамостійнюють різні світи: Платон - умоглядний, вічний i досконалий світ ідей (пов'язаний в єдине ціле 3 похідним земним світом), а Арістотель - сам цей земний світ. Ю. Шичалін наголошує на «іманентизмі» Арістотеля, вказує на його «прагнення не виходити за межі тутешнього світу при розгляді трансценденталій, тобто того, що безпосередньо не дано нам ні в відчутті, ні в розумі», і про непохитну переконаність Стагірита «в тому, що данність явленого світу - вічна, безумовна і остаточна» [18, с. 131]. Тому Арістотель - це природоцентрист, занурений у вивчення фізичного світу та природничих наук. Стагірит - це філософ, з якого, на думку істориків, починається наука; мислитель, що черпає 3 джерел поняттєвого мислення; довершений інтеллектуаліст, в якому вчений раз у раз бере гору над філософом. І якщо софійно-платонічне філософування, будучи мотивованим, зрештою, прагненням до єд- 
нання 3 божеством, спрямоване по вертикалі, то епістемноарістотелічне тяжіє до горизонталі, до ствердження самодостатності світу речей-субстанцій. Інтуїт Рафаель, як не раз відзначалось, це відчував. У його картині «Афінська школа філософів» Платон і Арістотель вказують у діаметрально протилежних напрямках: Платон - пальцем догори, а Арістотель - долонею донизу.

Вчення Платона (і платонізму) - це філософське alter ego peлігії. Він - філософ-богослов, а платонізм - це, як дещо епатажно висловлюється православний монах О. Лосєв, «догматичне богослів'я» [24, с. 833]. Але приблизно таким самим бачить Платона i томіст Е. Жільсон. Отці церкви, зазначає він, розрізняли серед філософських вчень найбільш близькі до християнства, і Платон набирав серед них найбільше «очків», до того ж «найважливіших». Він $є$ союзником християн за багатьма засадничими ідеями свого вчення: «про деміурга Всесвіту; про Бога-Промислителя; про існування надчуттєвого божественного світу, лише відображенням якого $є$ світ чуттєвий; про духовну природу душі і ії зверхність над тілом; про освічення iї Богом; про iї нинішню рабську залежність від тіла і необхідність боротьби заради підкорення тіла душі; накінець, про безсмертя душі та про іiі загробне життя, де душа отримує нагороду або покарання за свої вчинки» [15, с. 71]. До того ж, божественна тріада Платона нагадує святу Трійцю християн: Деміург Отця, Ум - Сина, а Душа світу - Святий Дух. Словом, підсумовує Е. Жільсон, «важко уявити філософію, яка, не будучи релігією, була б до неї такою близькою» [15, с. 71-72]. Це розумів і еллініст, критик християнства Ф. Ніцше, за відомим афоризмом якого, християнство - ие платонізм для народу.

Останнім етапом розвитку платонізму в античності був започаткований Плотіним неоллатонізм, в якому головна мета філософії збігається 3 найвищою метою релігії. Якщо Платон, зауважує К. Ясперс, розумів філософування як богоуподібнення, то «Плотін - як єднання з божественним» [43, с. 129]. Життя поза Богом філософ переживав як стан «вигнання» і поривання «розміститися в Ньому (в Богові. - В. Б.) заради сповнення Ним» [Еннеади, VI. 9, 7; цит. за: 34]. Кому це, як Плотіну, вдається, той бачить себе «як саме 
чисте світло, - позбавленим важкості, легким, тим, що закінчив становлення, а ще краще сказати.., - богом») [Еннеади, VI. 9, 9; див. також: Еннеади, VI. 7, 34, 36]. За свідченням найближчого учня і видавця творів Плотіна Порфирія (233-301/305), «зближення і возз'єднання із загальним богом є для нас гранична мета», якої його вчитель досяг чотири рази, а Порфирій один раз, на 68-му році життя [35, с. 475]. Пізніші визначні неоплатоніки Ямвліх Халкідський (бл. 245-325) і Прокл Діадох (бл. 412-485) - це і мислителі і теурги-чудотворці [див.: I, с. 57-58], які шукали вже «не так задоволення для розуму, як безпосереднього спілкування з божественним», намагаючись «сумістити у цілісній системі філософію і релігію» $[28$, с. 112].

Натомість Арістотель, відзначає Г. Майоров, позбавляє Бога таємничості. Він іманентний (а не трансцендентний, як у Платона) природі і $\epsilon$ «раціонально-вивідним іiі початком і завершенням» [27, с. 338]. Тому богослів'я Стагірита збігається з метафізикою, 3 раціональною наукою про суще в його «граничному самовираженні» [27, с. 338]. Арістотелів Бог як першодвигун і першоджерело форм є розум (voṽs), заглиблений у «мислення про мислення» [Mетафізика XII, 9, 1074b 15-34], чим дуже нагадує філософа. Ця теологія тяжіє до перетворення філософського розуму на «бога», відтак - і до раціоцентризму, до контроверз теоцентризму й людинорозмірного раціоцентризму у схоластиці. Схоласти, не знайшовши у вченні Стагірита істотних перетинань з християнством, проголосять Арістотеля «Предтечею Христа в тому, що стосується речей природних» [Praecursor Christi in naturalibus] [3, c. 413]. «Правдиво кажучи, - вважає О. Койре, - арістотелізм несумісний навіть із самим поняттям розвиненої релігії» [21, с. 72, прим. 19], зокрема 3 «духовною позицією» християнства або ісламу [21, с. 63]. Гордість Арістотеля, його «Органон» - це формально-логічний інструмент створення формально-логічно несуперечливих ментальних образів реальності, теологічних «сум», але не досвідного єднання із самим Богом.

Отже, на піку піднесення давньогрецької філософської думки два генії-антиподи створили контрастуючі і, як виявилося з часом, базові філософські вчення, за одним 3 яких («софійним») філосо- 
фію вбачали, висловлюючись сучасною термінологією, інтегральним екзистенційно-когнітивним способом світоглядного самовизначення людини та ії вивищення над собою заради богоуподібнення через поєднання з Богом (перехід у «рід богів»), а за другим («епістемним»), яке опустило «світ ідей» у «світ речей», відновивши «права досвіду й конкретного спостереження» [5, с. 730], філософія постала «як дослідницько-теоретичне вивчення реально існуючого» [37, с. 117], як «наукова філософія» [37, с. 33] або «наука наук» $[27$, c. 21$]$.

Античність, таким чином, породила дві важливі, з огляду на нашу тему, полярності: полярність ментальності народів Греції та Риму і щойно зазначену полярність софійно-платонічного й епістемно-арістотелівського типів філософування. У своїх перетворених формах ці «зерна розділення» дадуть себе взнаки пізніше, вже у середньовіччі.

Одним 3 визначальних цивілізаційно-культурних чинників нової християнської епохи, зокрема європейського Середньовіччя, стало явище і вчення Ісуса Христа, що заклали основу нової духовності. У середньовічно-християнських контекстах філософія втратила свою колишню - часів Античності - вищість і схилилася перед панівним становищем релігії та християнської церкви. Ми входимо у світ, де, перефразуючи Е. Жільсона, філософами є ченці і священики, де філософія інтегрована в богослів'я, а воно претендує на роль філософії.

Ідеологічно-культурно Середньовіччя починалося 3 появи першої християнської держави після проголошення двох візантійсько-імператорських едиктів: Міланського - Константином I (313 р.) і антиязичницького - Феодосієм I (391р.). Перший легалізував християн, а другий надав християнству статус державної релігії. Через чотири роки після цього сталося підмуркове для прогресуючого політичного розколу Свропи розділення єдиної Римської Імперії на Західну $і$ Східну. Центром першої залишався старий Рим, а столицею другої - проголошене ще в 330 р. «Новим Римом» місто Візантій, перейменоване на Константинополь. На Заході мовою церкви, відтак і культури, стала латина, а на візантійському 
Сході - грека. Згодом, «латинський Захід поширив свій вплив на германські народи, грецький Схід - на слов'янські. У результаті утворилися два несхожі духовні світи: романо-германський та візантійсько-слов'янський» [27, с. 129]. Поруч із Західною Європою виникає «інша Європа» - Візантія, кожна з яких, поділяючи спільні цінності, плекала свій варіант європейської культури [див.: 22, c. 272].

Проявом, що унаочнює їх істотної неподібності, стало чергове розділення, на цей раз - иерковно-віросповідне, розполовинюючи те, що було спільним для західним і «візантійських європейців» (А. Лідов) і об’єднувало їх - Християнську церкву (і християнство). Вона не витримала розмиваючих єдність чинників. Відмінності в соціально-історичних обставинах, географія, спільність мови i ментальності природно й неминуче єднали одних з латинською культурою, а інших - 3 грецькою, формуючи в західних європейців та візантійців різні призми, крізь які ті й інші бачили самих себе і світ. У будь-якому разі, взаємовідчуження почалося вже з перших століть і з часом лише посилювалося. Римська церква вже тоді, а цілком виразно пізніше, відзначалася бурхливо-активною діяльністю, спрямованою більше назовні, а східні християни - діяльністю, спрямованою більше всередину. У Римі від початку прагнули змінити світ, добитися ствердження світової теократії, яка мала б підпорядкувати всіх християн папській юрисдикції, натомість священство і чернецтво Візантії, яке задавало тон тамтешньому християнству, прагнули змінити насамперед себе. Зростаючі взаємонепорозуміння і конфлікти, зрештою, закінчилися неминучим: після обміну сторін анафемами Християнська церква розділилася в 1054 р. на Римсько-католицьку («латинську») і Візантійсько-православну («грецььку»).

Вони обидві перетерпіли, за А. Гарнаком, «еллінізацію», але за різними лекалами, реалізуючи різні типи синтезу античності та християнства (і відповідно, різні типи богословствування та філософствування). «Формується дуалізм католицької і православної культур» [5, с. 732]. I було б дивно, коли б за розбіжностями, які закінчилися розколом Церкви і дуалізмом культур, не ховалися не менш гострі відмінності у виборі сторонами своїх філософських 
учителів та панівних парадигм, або типів філософування. I вони, ці відмінності, звичайно ж $є$.

Універсальне духовне вчення Христа почали адаптувати до тогочасного рівня людської свідомості і перетворювати на релігію під патронатом Церкви, почасти вже апостоли, згодом апологети, а остаточно - св. отці епохи патристики. За відмінностями мови та менталітету вона ділиться на грецьку, або східну, і латинську, або західну. Вони, як і культури, на грунті яких виникли, істотно відрізняються одна від одної, навіть зовнішньо. Грецька патристика виникла раніше латинської й продовжувалася значно довше від неї. Остання виникає лише в середині III ст. (коли латина стає літургійною та літературною мовою Заходу) і закінчується в VI ст. (на папі Григорії Великому, який помер у 604 р.), а грецька почалася з I ст. і номінально нібито закінчилася на I. Дамаскині (VIII ст.), а фактично продовжувалася до падіння Константинополя (1453 р.).

Але що значно важливіше, латинська патристика, на відміну від грецької, органічно переросла в домінацію схоластики, тоді як iii прояви на візантійській історичній арені - це, зазвичай, явище маргінальне і ніколи не дійство переднього плану. Схоластика тут ніби і є, а ніби іiі і немає. У східній релігійній думці, як запевняє В. Лосський, «ніколи не було своєї схоластики» [26, с. 80], а якщо вона й була, то, зауважує Г. Майоров, отримала тут значно менший розвиток, ніж на Заході [див.: 27, с. 88] і до неї, доводить С.Аверніцев, «не зовсім застосовно поняття схоластики» [2, с. 143].

У будь-якому разі, візантійська протосхоластика не змогла ні витіснити, ні замінити собою магістральну для візантійців «патристику після патристики». I у грецькій святоотчій традиції поміж святих і отців церкви немає жодного схоласта. Натомість серед католицьких святих бачимо «блаженного» Дунса Скотта (біля 12661308), а поміж вчителів латинської церкви - св. Ансельма Кентерберійського (1033-1109), св. Альберта Великого (1193 або 1206/1207-1280), св. Бонавентуру (1217-1274) і св. Тому Аквінського (1224-1274). Усі вони світочі схоластики, яка, судячи навіть 3 цього, була так само органічною католищизму, як неприродною православ'ю. Тому у Візантії патристика класичної доби I-VIII ст. 
переросла не в домінацію схоластики, а, як побачимо далі, в зовсім інший, софійний за нашою типологією, філософський і богословський феномен.

Перше, що віддавна кидається в очі патрологам і візантологам, $є$ те, що римо-католицький Захід доби схоластики (це IX-XIV ст., за С. Аверинцевим), спираючись і на платонізм і на арістотелізм, успадковує як власне парадигмальний для своєї теології та філософії епістемно-арістотелівський тип філософування, а православний Схід, за всіх коливань, посутньо невпинно продовжує як парадигмальну для своєї культури, панівну в Античності, софійноплатонічну лінію філософування. Ця теза, звичайно, вимушено дещо схематизує різнобарвність реальної філософсько-богословської думки католиків і православних, але на це немає ради. Усе, що існує, $є$ тим, що воно $\epsilon$, через заперечення того, чим воно не $\epsilon$. I «матриці», або коди цивілізацій підлягають цьому правилу, як і все інше. До того ж, назване бачення є досить поширеним. Таким, що увійшло навіть у підсумовуючі наукові дослідження довідкові видання. Так, автор статті «Свропейська філософія» в німецькому «Філософському словнику» (22-му переробленому виданні 1990 р.) вбачає відмінність між «Візантією і Парижем (Центром Західної Європи)» саме в тому, що, на відміну від нього, «провідним філософом у Візантії був не Арістотель, батько логіки, а Платон» [37, с. 154]. І це підтверджується фактами історії.

Західне Середньовіччя починалося із занурення в «темні віки» політичного, економічного та інтелектуального варварства (VIXI ст.), подолавши яке, Західно-Центральна Європа пізнала з IX по XIV ст. «виключно плідну, безприкладну за інтенсивністю інтелектуального та художнього життя» епоху [21, с. 51], випереджаючи в ряді напрямів занепадаючу, особливо з XII ст., Візантійську цивілізацію. Те варварство, на думку істориків, зумовлюється не так окупацією германськими племенами романського світу, «як розривом стосунків між Сходом і Заходом, між латинським світом і світом грецьким» [21, с. 52]. Тому пізніше відродження Заходу пов'язане передусім 3 поновленням контактів з грецькою спадщиною. Поновленням, яке спочатку відбулося через арабських посередників, які 
на диво грунтовно засвоїли науку і філософію греків і рухалися в бік «ісламізації» Арістотеля.

У V-VI століттях Західна Європа, за даними істориків, перестає розуміти грецьку мову і втрачає доступ до грецьких оригіналів у галузях науки, філософії та літератури [див.: 23, с. 7-9]. До розділення «двох світів», відзначає Е. Деларюель, кількість зроблених перекладів «була досить незначною»; «латинський світ жив, замкнувшись у собі, під ковпаком». I це, наголошує вчений, факт історії культури, «значення якого не можна перебільшити» [цит. за: 23, с. 9, прим.]. Ситуація нагадувала справжнє «суднотрощення», пише Поль Деларю. «Виплили кілька рідкісних уламків: для платонізму це латинський коментар» на «Тімея», написаний наприкінці III або на початку IV ст. Халкідієм і його ж неповний, «уривчастий» переклад «Тімея»; для неоплатонізму - це коментар Макробія до «Сну Сціпіона» та «відблиск «Еннеад», помітний у св. Августина, який знав їх частково у нині втраченому перекладі Вікторина» [23, с. 9-10]. I це все. Принаймні до Х ст. Але жоден 3 творів самого Платона не удостоївся перекладу на латину і пізніше, в XI-XII ст. Не чутно про такі переклади і в XIII ст. I це вже не випадковість. Переклади здійснювалися «в самій Греції, в грекомовних країнах Південної Італії (Королівство Обох Сицилій) і в Іспанії» [9, с. 71]. У перших двох рукописи Платона, вочевидь, були. Їх просто не перекладали. Проте в ХІІІ ст. Захід отримав доступ до неоплатонізму Прокла (переклади Вільгельма з Мербека в 12681281 pp. «Першооснов Теології», коментарів на «Тімея» і на «Парменіда»), до ісламського (аль Фарабі (870-950), Авіцени (9801037), Авероеса (1126-1198)) і до єврейського (Гібероля (1020/1021-1069/1070)) неоплатонізму та до таких просякнутих неоплатонізмом творів, як «Теологія Арістотеля» і «Книга про причини». Якщо додати до цього доступ до християнського неоплатонізму Августина і Ареопагітик, то можна говорити про достатньо широкі можливості для західних інтелектуалів долучитися, нехай не до першоджерел платонічно-неоплатонічної думки, але все ж до авторитетних іï знавців. 
Тому про платонізм у католицькому середньовіччі Е. Жільсон пише, вдаючись до парадоксу: «Самого Платона немає ніде, але платонізм - скрізь» [15, с. 203]. То був платонізм, що спирався на поінформованість про певні ідеї, концепції, висловлювання Платона (і Плотіна), але не на їх тексти, не на повноцінне перетворення світогляду і способу думання Платона у факт власного світосприйняття і метод мислення. На переконання О. Койре, «платонізм св. Августина, Роджера Бекона, або св. Бонавентури, не був платонізмом Платона - йому було далеко до цього» [21, с. 62]. I все ж «думка Платона мала якнайглибший вплив на середньовіччя, яке майже не знало ії текстів. Вона засвоювалась через посередництво різних вчень, що зазнали ії безпосереднього або опосередкованого впливу» [14, с. 99]. Течію середньовічного платонізму Е. Жільсон порівнює з рікою, що бере початок у платонічних мотивах творчості Августина і розширяється за рахунок притоків різних «платонізмів» - Боеція, Діонісія Ареопагіта, I. Еріугени, Авіценни та ін. [див.: 14, с. 95].

Але хоча «платонізмів» було багато, до філософської теології власне софійного типу Г. Майоров однозначно відносить вчення одного Августина, зауважуючи при цьому, що «розуміння сутності та функції філософії» визначав не августинізм, а «схоластичний арістотелізм, який починає свою історію з Боеція» [27, с. 66].

Зовсім інакше, мало не з VI ст., виглядає ситуація у Західній Європі з текстами Арістотеля і взагалі з арістотелізмом.

Той таки Боецій (помер бл. 525 р.) вдруге, після Марія Вікторина (помер після 363 р.), переклав «Ейсагог» (вступ до «Категорій» Арістотеля) Порфірія і всі основні трактати Стагірита 3 логіки [див.: 7, с. 304]. I хоча частина перекладів була втрачена, те, що збереглось, укупі з логічними працями самого Боеція, слугувало основою вивчення арістотеліанської логіки і становлення початків схоластики.

Могутній поштовх арістотелізації латинської філософії надав ірано-арабський арістотелізм, переклади творів якого хвилеподібно накрили Західну Європу: «араби, - відзначає О. Койре, - стали вчителями і вихователями латинського Заходу» [21, с. 52]. Адже тут не було на той час знавців філософії, щоб розуміти складні за 
змістом «Метафізику або «Фізику» Стагірита. Араби по-своєму сприйняли вчення Платона і Арістотеля і були високої думки про останнього. За Авероесом, філософія Арістотеля - це найвища істина, його розум - «вінець людського розуму», а сам філософ - посланець Провидіння, «щоб ми знали все, що можемо знати» [цит. за: 6 , с. XIII].

У першій половині XIII ст. західноєвропейці могли читати у латинських перекладах всі відомі Античності твори Арістотеля i, наприклад, за статутом від 19 березня 1255 р. викладачі факультету мистецтв Паризького університету повинні були викладати на своїх лекціях теж всі твори Арістотеля. Починається, або настає новий етап інтенсивного «вростання» тепер вже християнського арістотелізму у ментальність і культуру західноєвропейців, який вносить при цьому «ні з чим не порівнюваний внесок у становлення специфіки Заходу», - вважає С. Аверінцев [5, с. 734-735].

I все це здійснювалося головним чином у схоластиці і через неї. Вона, як ми вже відзначали, зародилася в лоні латинської патристики і коли вийшла 3 пелюшок, то замінила ії як нова форма християнської філософії. У ній намагалися раціонально обгрунтувати те, в що раніше, здебільшого, вірили, спираючись на «природній розум» людини. «Це застосування розуму до потреб віри і в самій вірі, але таке, що, зрештою, набуло наукової форми і $є$ схоластика, - пояснює Е. Жільсон. - Порівняно з працями Отців Церкви схоластика - це не так нова доктрина, як новий інтелектуальний стиль, що відповідав тому часу, коли християнська традиція, несподівано збагачена арістотелізмом, засвоїла велику кількість нових наукових та філософських понять» [13, с. 153]. У схоластиці різко зросла роль філософії і питома вага раціональних методів міркування. Схоласти, як і св. отці, богословствували, але філософуючи. За об'єктом рефлексії - то була теологія, а за раціональною методологією теоретизування - філософія.

Теологія спиралася на одкровення, а філософія (в тому, чим вона відрізняється від теологіï) - на розум (ratio). Перше й друге вбачали протилежностями, і то - неусувними, бо віра й розум - це не те, чим можна знехтувати. Їх треба було якось примирити. Ця 
проблема - головний біль церковних лідерів католицизму й ключове завдання схоластики.

У Римі підшуковували того, хто міг би справитися з цим завданням i, зрештою, звернули увагу на подаючого великі надії домініканця Тому Аквінського (1225/1226-1274). Він виправдав надії пап (Урбана VI та Климента IV). У своєму монументальному синтезі (у київському виданні «Ніка-Центру» це 12 книг, 6464 стор.) «Сумі теології» (1266-1273). Тома перетворив загрожуючого церкві язичницькими «єретизмами» Арістотеля на цілком благонадійного «Арістотеля з тонзурою» (О. Герцен), довівши, що, коли витлумачити його певним чином, то можна скористатися його способом мислення для обгрунтування християнства. Аквінатова «Сума» стала з часом однією з найголовніших книг церкви, його томізм - іï офіційною філософією і теологією, а сам Тома - «учителем» церкви, отримавши прізвисько «государя схоластів».

Середньовічний католищизм - иее християнство, яке усвідомлює себе в теології $і$ філософії схоластів (насамперед Аквіната), які спиралися на синтез біблійного одкровення 3 логікою та методологією передусім Арістотеля (із залученням ідей платонізму i неоплатонізму). «За всіма вченнями», які спростував Т. Аквінський, він, пише Е. Жільсон, «вгадує духовну присутність платонізму. Якщо він їх відкидає, то саме тому, що в його очах світ, що підлягає філософському витлумаченню, є реальний світ Арістотеля, а не заселений привидами світ Платона» [14, с. 231].

Ця виключна зосередженість на арістотелізмі - велика новина в історії.

Ретельно проаналізувавши еволюцію античного платонізму, Ю. Шичалін переконливо довів, що ми «маємо всі підстави для висновку, що античний платонізм - несуча конструкція всієї будівлі античної філософії» [40, с. 318]. Отже, першим і найголовнішим розумом Античності був софійно-платонічний (а не епістемноарістотелівський). Зоряний час Арістотеля настав пізніше - у середньовічній латинській культурі.

Якщо у східному християнстві аж «до самого падіння Візантії головним напрямом філософування лишався християнський платонізм» [27, с. 65], то католики обрали своїм провідником у світ 
містика Ісуса не містика Платона, а того, хто «менше філософ і більше вчений-емпірик» [20, с. 266] - Арістотеля. Він - батько схоластики, іiі патріарх. Без нього іiі важко уявити. Та й чи була б вона взагалі без Стагірита? Саме він наділяється в ній статусом Філосо$\not a$. Устами дисиденствуючого (й тому трагічно закінчившого свій життєвий шлях) Сігера Брабантського (1240-1280) вона проголосила Арістотеля своїм божеством: «Я стверджую, - запевняв Сігер, - що Арістотель досяг у науці досконалості, бо ті, що йшли за ним аж до нашого часу, тобто впродовж майже п'ятнадцяти століть, нічого не змогли додати до його праць, або віднайти якусь істотну помилку... Арістотель $є$ божественною істотою» [цит. за: 11, с. 102]. Навіть августиніанці, більше того - містики, наприклад, св. Бонавентура, викладають свої вчення переважно у формах епістемно-арістотеліанського, а не софійного філософування. Що, зрештою, зрозуміло. «Схоластика - це культура ratio, культура розсудка, а не духа» [27, с. 66]. Культура культу формальної логіки і «строгої, впорядкованої науки (scientia ordinata)», в контексті якого філософію і навіть теологію (Аквіната, Дунса Скота) відносять до розряду «scientiae» [27, c. 67].

Схоластика була досить багатоманітна. Крім домініканського напряму, був францисканський (Роберт Гротессет (1175-1253), Роджер Бекон (бл. 1214-1294), Бонавентура (1221-1274), Дунс Скот (1270-1308) та ін.). Крім томізму - скотизм, започаткований глибоким i, за рідкісним даром нюансування думки, навіть віртуозним мислителем, Дунсом Скотом. У фокусі домініканців - розум (загальне), а скотистів - воля (і одиничне). Францисканці шанували, як правило, св. Августина. Платонізуючий августинізм поступився тоді за поширеністю тільки арістотелізму.

Не бракувало західному християнству і містиків. Вони скарб кожної повноцінної релігії. У даному разі йдеться про теологів-містиків, яких тут специфікує схоластичний склад розуму. Навіть найуславленіший серед них, Майстер Екхарт (1460-1327) не став винятком [див.: 37, с. 258]. Схоластичні трактати - один зі складників його літературної спадщини. усі західні містики перебували під визначальним впливом платонізму (і неоплатонізму), 
точніше, як відзначає знавець католицької містики Л. Карсавін, «надихалися платонізуючою думкою Сходу» [19, с. 15]. То були містики, за означенням Е. Жільсона, «спекулятивні», або «умоглядні». Основоположником містичного умогляду католицизму був Бернард Клервоський (1090-1153) і вікторіанці (Гуго СенВікторський (1096-1141) і Рішар Сен-Вікторський (помер у 1173)), погляди яких, пізніше систематизовані св. Бонавентурою, повторялися, за Л. Карсавіним «майже всіма містиками католицизму» [19, с. 15]. Дещо осібною була, теж візантійська за своїми платонічними джерелами, німецька містика (Екхарт, I. Таулер (1300-1361), Г. Сузо (1300-1365)). «Містичний напрям теології, що виходив 3 данностей «внутрішнього досвіду» і з недовірою ставився до логічних викладок», пробував у цій церкві «дати бій схоластиці (Бернар Клервоський проти Абеляра)», але змушений був «схилитися перед останньою» [4, с. 440]. Натомість, на християнському Сході духовна ситуація склалася зовсім інакше: тут містичний напрям заблокував появу повноцінно-схоластичного.

Ця, конспективно намічена позірна «мішанина» арістотелізму, августинізму, платонізму і неоплатонізму не відміняє іманетносутнісного зв'язку схоластики передусім саме з арістотелізмом, його визначальності, як у іiі генезі, так і в прикметному для схоластики формально-логічному дедуктивно-аксіоматичному способі мислення. У сутності немає мішанини. Вона може бути лише в явищі. У схоластики був батько «зовнішній», історичний (одні бачать таким Боеція, інші - Ансельма Кентерберійського, ще декого), але був і «внутрішній», духовний. І це не Августин, не Платон і не Плотін, а все-таки Арістотель. У неї були різні ідейні джерела, але головне - арістотелізм. Вона виникла і розквітла саме тоді, коли він опанував думкою богословів і філософів Заходу, потіснивши загалом чужий йому поміркований платонізм патристики. Починаючи 3 XIII ст., католицька наука, за деякими винятками, «завжди залишилася наукою, що йшла за Арістотелем» [19, с. 38].

Інтенсивна філософізація християнської думки у схоластиці супроводжувалася всеохопною іiі арістотелізацією. Схоласти, будучи синами Католицької церкви й учнями Христа, намагалися християнізувати Арістотеля, а в якості його учнів (підсвідомо) - 
арістотелізували християнство. Свідоме покатоличення Арістотеля 3 неминучістю - усвідомлювали це чи ні, - супроводжувалося тонкою арістотелізацією католицизму.

А оскільки Арістотель - це змирщувач Платона, можна 3 великою імовірністю припустити, що арістотелізація католицизму, його богослів'я, мала супроводжуватися і їх змирщенням. Християнство «втілилося й розвивалося» в католицизмі (як і в інших своїх втіленнях) «однобічно і обмежено» [19, с. 15]. Східне християнство вважається більш космічним, а західне поставило «космос нижче людини» [19, с. 50] і тяжіє до антропоцентризму, до приймання й освячення всього людського; до визнання прав людини, «на здійснення прагнень своєї природи» [19, с. 69]; до боротьби за мирську владу й проникнення «в гущу й дрібниці суспільного життя» [19, с. 38] тощо. Відмежовуючись «від надмірної споглядальності, властивої східному християнству», католицизм зосереджується на грунтовній розробці й систематизації «практичної сторони християнства» [19, с. 38], а посутньо - на пристосуванні людини до світу, на примиренні з ним.

Одним з небагатьох, хто глибоко розібрався в особливостях арістотелівської закваски і наслідках заквашення нею західної культури, є С. Аверінцев. Виходячи зі згаданого раніше схоластичного бачення Арістотеля «предтечею Христа у тому, що стосується речей природних», вчений з'ясовує значення, смисл цієї царини природнього. Християнство, міркує С. Аверінцев, ділить буття надвоє: Бог - диявол, Христос - антихрист, рай - пекло, «діти світла» - «слуги пітьми» тощо. Але різні філософські контексти можуть або наголошувати на дихотомії, або іï пом'якшувати, опосередковувати. Для платонізму, з його орієнтацією на «абсолютні принципи», прикметно перше, для арістотелізму - друге. «Розлучившись 3 чистим августинізмом у часи Аквіната, - пише С. Аверінцев, - католицький світогляд в його панівній формі ділить буття не надвоє «світло» і «пітьма», - а натроє: між небесною областю надприроднього та інфернальною областю протиприродного цього еону живе за своїми законами, хоча і під владою Бога, сфера природнього» [5, с. 735], що регулюється арістотелівським законом правиль- 
ної міри і моральними нормами, угодами, соціальними конвенціями тощо.

Отже, Арістотель допоміг західноєвропейцям ослабити дихотомії християнства через філософську легітимацію опосередковуюче-серединної поміж «небом» і «пеклом» сфери природного, іншими словами - через світоглядну реабілітацію власне мирської життєдіяльності, врегульовуваної церквою та державою.

Вважаємо, є всі підстави погодитися і з підсумковими висновками двох знаних медієвістів. Річ не в тому, відзначає Л. Карсавін, що католики «звикли» висловлюватися «мовою арістотелівської схоластики», «а в тому, що арістотелізм своӥм оберненням до землі та людини краще відповідає духові католицизму» (Курсив мій. В. Б.) [19, с. 39].

Доповнюючи i поглиблюючи думку Л. Карсавіна, С. Аверінцев резюмує: «Людина Заходу може ніколи не читати Арістотеля; може ніколи не чути цього імені; може вважати себе переконаним противником усього, що пов'язане з цим іменем. I все ж вона у певному сенсі $є$ «арістотеліанцем», бо вплив арістотеліанської Схоластики за століття визначив надто багато, аж до несвідомо вживаних лексичних зворотів. Тому людина сучасності добре зробить, якщо частіше думатиме про арістотелізм як внутрішню форму західної цุивілізацї̈» (Курсив мій. - В. Б.) [5, с. 738].

Отже, у розділеній на християнський Захід і християнський Схід середньовічній Європі кожна $з$ цих двох частин, спираючись на спільну для них релігійну основу своїх культур, виявилася більш відкритою для сприйняття й екзистенційно-світоглядної асиміляції полярно протилежних філософій. I хоча вчення Платона/Плотіна i Арістотеля знали й використовували як у католицькому світі, так і в візантійсько-православному, іманентно-внутрішнім для кожного 3 них було все-таки переважно (але не виключно) одне 3 них: для середньовічно-латинської схоластики це християнський арістотелізм, а для візантійсько-православної духовності, як побачимо у наступному дослідженні, християнський платонізм/неоплатонізм. 


\section{ЛITEРАТУРА}

1. Аверинцев С. С. Эволюция философской мысли. Культура Византии IV-первой половины VII в. / отв. ред. З. В. Удальцова. Москва : Наука, 1984.

2. Аверинцев С. С. Византийская философия. Аверинцев С. С. София-Логос. Словарь / ред. Н. П. Аверинцевой и К. Б. Сигова. Киев : Дух і Літера, 2006. С. 138-144.

3. Аверинцев С. С. Схоластика. Аверинцев С. С. София-Логос. Словарь / ред. Н. П. Аверинцевой и К. Б. Сигова. Киев : Дух і Літера, 2006. C. 410-417.

4. Аверинцев С. С. Теология. Аверинцев С. С. София-Логос. Словарь / ред. Н. П. Аверинцевой и К. Б. Сигова. Киев: Дух і Літера, 2006. с. 434-443.

5. Аверинцев С. С. Христианский аристотелизм как внутренняя форма западной традиции и проблемы современной России. СофияЛогос. Словарь / ред. Н. П. Аверинцевой и К. Б. Сигова. Киев : Дух і Літеpa, 2006. С. 729-738.

6. Аполлонов А. В. Фома Аквинский и антиавероистская полемика 70-х годов ХІІІ столетия. Фома Аквинский. Сочинения / пер. с лат., ввод. статья и ком. А. В. Аполлонова. Изд. 2-е. Москва : Едиториал УРСС, 2004. C. V-XXX.

7. Аристотель. Сочинения: В 4-х т. / ред. В. Ф. Асмус. Москва : Мысль, 1976. Т. І. 550 с.

8. Бородай Т. Ю. Боэций. Новая Философская Энциклопедия: В 4-х т. Москва : Мысль, 2010. Т. І. С. 304-306.

9. Вульф Морис, де. Средневековая философия и изивилизиия / пер. с англ. О. Д. Сидоровой. Москва : ЗАО Центрполиграф, 2014. 253 с.

10. Гайденко П. П. Средневековый номинализм и генезис новоевропейского сознания. Вопросы философии. 2014. № 2. С. 155-163.

11. ГоффЖ. Л. Интеллектуальв в средние века / пер. с фр. А. М. Руткевича. 2-е изд. СПб. : Изд-во Петербургского ун-та, 2003. 160 с.

12. Диоген Лаэртский. О жизни, учениях и изречениях знаменитых философов / ред. и вступ. статья А. Ф. Лосева. Москва: Мысль, 1979. $620 \mathrm{c}$.

13. Жильсон Э. Философ и теология / пер. с фр. К. Демидова. Москва : Гнозис, 1995. 195 с.

14. Жильсон Э. Избранное: Т. I. Томизм. Введение в философию св. Фомы Аквинского / пер. с фр. Г. В. Вдовиной, отв. ред. С. В. Лёзов. Москва : СПб. : Университетская книга, 1999. 496 с. 
15. Жильсон Э. Философия в средние века. От истоков патристики до конца XIV века / общ. ред., послесл., примеч. С. С. Неретиной. 2-е изд. Москва : Культурная революция; Республика, 2010. 678 с.

16. Жмудь Л. Я. Наука, философия и религия в раннем пифагореизме. СПб. : Изд-во ВГК; Алетейя, 1994. 376 с.

17. Зелинский Ф. Ф. Древнегреческая религия. Киев : Синто, 1993. $180 \mathrm{c}$.

18. История философии: Запад-Россия-Восток. Книга первая: Философия древности и средневековья. Москва : Греко-латинский кабинет, 1995. $480 \mathrm{c}$.

19. Карсавин Л. П. Католичество. Карсавин Л. П. Католичество. Откровения блаженной Анджель. Томск : Изд-во Водолей, 1997. С. 5-95.

20. Карсавин Л. П. Джсрдано Бруно. СПб. : Наука, 2016. 266 с.

21. Койре А. Аристотелизм и платонизм в средневековой философии. Койре А. Очерки истории философской мысли. О влиянии философских концепций на развитие научных теорий / пер. с фр. Я. А. Ляткера; общ. ред. и пред. А. П. Юшкевича. Москва : Прогресс, 1985. С. 51-73.

22. Лідов А. Лики і маски Візантії. «Візантійщина»: візантійський иивілізаційний спадок у Центрально-Східній Європі» / ред. А. Доманівський, О. Файда; укл. М. Доманівська. Харків : Майдан, 2018. C. 268-279.

23. Лемерль П. Первый византийский гуманизм. Замечания и заметки об образовании и культуре в Византии от начала до X века / вст. ст. и пер. с фр. Т. А. Сениной (монахини Кассии). Изд. 2-е, испр. СПб.: Изд. проект «Квадриум», 2017. XIV + 482 с.

24. Лосев А. Ф. Очерки античного символизма и мифологии / общ. ред. А. А. Тахо-Годи, И. И. Маханькова. Москва : Мысль, 1993. $962 \mathrm{c}$.

25. Лосев А. Ф. Римская философия. Лосеф А. Ф. Словарь античной философии. Москва : Изд-во «Мир идей», АО ЛКРОН 1995. С. 186192.

26. Лосский В. Н. Очерки мистического богословия Восточной Церкви. Догматическое богословие. Москва : Центр СЭИ, 1991. 288 с.

27. Майоров Г. Г. Философия как искание Абсолюта. Опыты теоретические и исторические. Москва : Едиториал УРСС, 2004. 416 с.

28. Мейендорф И., прот. Христос в восточном православном богословии / пер. с анг. свящ. О. Давыденкова при участии Л. А. Успенской, прим. А. И. Сидорова. Москва : ПСТБИ, 2000, 318 с. 
29. Мейендорф И., прот. Византийское богословие. Исторические тенденции и доктринальные темы / пер. с англ. В. Марутика. Минск: Лучи Софии, 2001. 336 с.

30. Мейендорф И., прот. Византийское влияние на русскую цивилизацию. Мейендорф И., прот.. Церковь в истории: Статьи по истории Церкви / пер. с англ., фр.; сост. И. В. Мамаладзе. Москва : Прав. Св.Тихонов. Гуманитар. ун-т: Эксмо, 2018. С. 661-677.

31. Наталя Яковенко. «Підручник української історії залишається бастіоном ура-патріотизму». Газ. «День». № 215(2011), 25. ХІ. Інтерв’ю брала Ганна Трегуб.

32. Окара А. Константинополь-Київ: Візантійська спадщина як фактор побудови нової української ідентичності. «Візантійщина»: візантійсько-цивілізаційний спадок у Центрально-Східній Європі / ред. А. Домановського, О. Файди. Харків : Майдан, 2018. С. 183-189.

33. Платон. Сочинения: В 3-х т. / пер. с древнегреч. общ. ред. А. Ф. Лосева, В. Ф. Асмуса. Москва : Мысль, 1970. Т. 2. 611 с.

34. Плотин. Шестая эннеада. Трактаты VI-IX в. / пер. с др.-греч. и послесл. Т. Г. Сидаша. СПб. : Изд-во Олега Абышко, 2016. 411 с.

35. Порфирий. Жизнь Плотина. Диоген Лаэртский. $О$ жизни, учениях и изречениях знаменитых философов / общ. ред. и вст. ст. А.Ф.Лосева. Москва : Мысль, 1979. С. 462-276.

36. Сорочан С. Б. Византийские парадигмы быта, сознания, кульmуры. Учеб. пособие. Харьков : Майдан, 2011. 952 с.

37. Философский словарь: Основан Г. Шмидтом. 22-е, новое, перераб. изд. / ред. Г. Шишкоффа; пер. с нем., общ. ред. В. А. Малинина, Москва : Республика, 2003. 575 с.

38. Фрагменты ранних греческих философов. Часть I. От этических теокосмогоний до возникновения атомистики. Подготовил А. В. Лебедев, Москва : Наука, 1989. 575 с.

39. Целлер Е. Очерк истории греческой философии / пер. с нем. С. Франк. Москва : Канон + РООИ Реабилитация, 2002. 352 с.

40. Шичалин Ю. А. История античного платонизма. В институцииональном аспекте. Москва : ГЛК, 2000. 439 с.

41. Штайнер Р. О технике мышления: восемь лекций 1908-1909 г2. I пер. с нем. Г. А. Кавтарадзе. СПб. : Ключи, 2015. 158 с.

42. Элиаде М. История веры и религиозных идей: От Гаутамы Будды до триумфа христианства / пер. с фр. Н. Б. Абалаковой, С. Г. Балашовой, Н. Н. Кулаковой, А. А. Старостиной. Москва : Академичекий Проект, 2009. 676 с. 
43. Ясперс К. Великие философы. Кн. ІІІ. Мыслящие из истока метафизики / пер. с нем. А. К. Судакова. Москва : Канон + РООИ «Реабилитация», 2021. 432 с.

\section{REFERENCES}

Averintsev, S. S. (1984). Evolution of philosophical thought. Byzantine culture of the IV-first half of the VII century. Z. V. Udaltsov (Ed.). Moscow: Nauka. [In Russian].

Averintsev, S. S. (2006). Byzantine philosophy. N. P. Averintseva \& K. B. Sigov (Eds.). Sofia-Logos. Dictionary (pp. 138-144). Kiev: Dukh i Litera. [In Russian].

Averintsev, S. S. (2006). Scholasticism. N. P. Averintseva \& K. B. Sigov (Eds.). Sofia-Logos. Dictionary (pp. 410-417). Kiev: Dukh i Litera. [In Russian].

Averintsev, S. S. (2006). Theology. N. P. Averintseva \& K. B. Sigov. (Eds.). Sofia-Logos. Dictionary (pp. 434-443). Kiev: Dukh i Litera. [In Russian].

Averintsev, S. S. (2006). Christian Aristotelianism as an internal form of Western tradition and problems of contemporary Russia. N. P. Averintseva \& K. B. Sigov. (Eds.). Sofia-Logos. Dictionary (pp. 729-738). Kiev: Dukh i Litera. [In Russian].

Apollonov, A. V. (2004). Thomas Aquinas and the anti-Averian polemics of the 70s of the XIII century. Thomas Aquinas. Essays (pp. V-XXX). Moscow: Editorial, URSS. [In Russian].

Aristotle. (1976). Essays: In 4 volumes. W. F. Asmus (Ed.). Moscow: Mysl, Vol. I., pp. 63-367. [In Russian].

Borodai, T. Yu. (2010). Boethius. New Philosophical Encyclopedia: In 4 vol. Moscow: Mysl. Vol.I, pp. 304-306. [In Russian].

Wulf Maurice, De. (2014). Medieval philosophy and civilization. (O. D. Sidorova, Transl). Moscow: ZAO Tsentrpoligraf. [In Russian].

Gaidenko, P. P. (2014). Medieval nominalism and the genesis of modern European consciousness. Voprosy filosofii [Questions of philosophy]. №2, 155-163. [In Russian].

Goff, J. L. (2003). Intellectuals in the Middle Ages. (A. Rutkevich, Transl.). St. Petersburg: St. Petersburg University Press. [In Russian]. 
$\overline{\text { Diogenes Laertius. (1979). On live, teachings and speeches of eminent }}$ philosophers.A. F. Losev (Ed.). Moscow: Mysl. [In Russian].

Gilson, E. (1995). Le Philosophe et la Théologie. (K. Demidova, Transl.). Moscow: Gnosis. [In Russian].

Gilson, E. (1999). Selected Works: vol. I. Thomism. Introduction to the philosophy of St. Thomas Aquinas. (G.. Vdovina, Transl.). Moscow; St.Ptb.: University Book. [In Russian].

Gilson, E. (2010). Philosophy in the Middle Ages. From the origins of patristic to the end of the XIV century. S. S. Neretina (Ed). 2 ed. Moscow: Cultural Revolution, Republic. [In Russian].

Zhmud, L. Ya. (1994). Science, philosophy and religion in early Pythagoreanism. St. Petersburg: VGK Publishing House; Aleteya. [In Russian].

Zelinsky, F. F. (1993). Ancient Greek religion. Kiev: Shinto.[In Russian].

The history of philosophy: West-Russia-East. Book one: Philosophy of antiquity and the Middle Ages. (1995). Moscow: Greco-Latin Cabinet. [In Russian].

Karsavin, L. P. (1997). Catholicism. In: Catholicism. Revelations of Blessed Angela (pp. 5-95). Tomsk: Aquarius. [In Russian].

Karsavin, L. P. (2016). Giordano Bruno. St. Petersburg: Nauka. [In Russian].

Koire, A. (1985). Aristotelianism and Platonism in medieval philosophy. Essays on the history of philosophical thought. On the influence of philosophical concepts on the development of scientific theories (pp. 51-73). (J. A. Lyatker, Transl.). Moscow: Progress. [In Russian].

Lidov, A. (2018). Faces and masks of Byzantium. In: Byzantine: Byzantine Civilizational Heritage in Central-Eastern Europe (pp. 268-279). A. Domanivsky \& O. Fayda (Eds.). Kharkiv: Maidan. [In Ukrainian].

Lemerle, P. (2017). Byzantine humanism, the first phase. Remarks and notes on education and culture in Byzantium from the beginning to the 10th century. (T. Senina, Transl.). $2^{\text {nd }}$ ed. SPb: Quadrium Project. XIV +. [In Russian].

Losev, A. F. (1993). Essays on ancient symbolism and mythology. A. A. TahoGodi \& I. I. Makhankova (Eds.). Moscow: Mysl. [In Russian].

Losev, A. F. (1995). Roman philosophy. In: Dictionary of ancient philosophy (pp. 186-192). Moscow: World of Ideas Publishing House, LKRON. [In Russian]. 
Lossky, V. N. (1991). Description of the mystical theology of the Eastern Church. Dogmatic theology. Moscow: SEI Center. [In Russian].

Mayorov, G.. G.. (2004). Philosophy as a search for Absolute. Theoretical and historical Experiences. Moscow: URSS Editorial. [In Russian].

Meiendorf, I., rev. (2000). Christ in Eastern Orthodox Theology. (O. Davydenkova \& L. Uspenskaya, Transl.). Moscow: PSTBI. [In Russian].

Meiendorf, I., rev. (2001). Byzantine theology. Historical trends and doctrinal themes. (V. Marutik, Transl.). Minsk: Luchi Sofii. [In Russian].

Meiendorf, I., rev. (2018). Byzantine influence on Russian civilization. His own. The Church in History: Articles on the History of the Church (pp. 661677). (I. Mamaladze, Transl.). Moscow: St. Tikhon Orthodox Humanitarian University: Exmo. [In Russian].

Yakovenko, N. (2011). The textbook of Ukrainian history remains a bastion of yay-patriotism. Den [Day], 215, 25. XI. Anna Tregub's interview. [In Ukrainian].

Okara, A. (2018). Constantinople-Kyiv: Byzantine heritage as a factor of building a new Ukrainian identity. «Byzantine world»: Byzantine-civilizational heritage in Central-Eastern Europe (pp. 183-189). A. Domanovsky \& O. Fayda (Eds.). Kharkiv: Maidan. [In Ukrainian].

Plato. (1970). Works: In 3 vol. Ancient-Greek transl. A. Losev \& V. Asmus (Eds). Moscow: Mysl. Vol. 2. [In Russian].

Plotinus. (2016). The sixth Ennead. Treatises of the VI-IX centuries. AncientGreek transl. and the aftermath. SPb.: Oleg Abyshko Publishing House. [In Russian].

Porphyry of Tyre. (1979). Life of Plotinus. In Diogenes Laertius. On live, teachings and speeches of eminent philosophers (262-276). A. Losev (Ed.). Moscow: Mysl. [In Russian].

Sorochan, S. B. (2011). Byzantine paradigms of life, consciousness, culture. Training manual. Kharkiv: Maidan. [In Russian].

Philosophical Dictionary (2003). G.. Schmidt (Founded). (G.. Shishkoff. Transl.). Moscow: Respublika. [In Russian].

Fragments of the works of early Greek philosophers. Part I. From ethical theocosmogony to the emergence of atomistics (1989). Moscow: Nauka. [In Russian]. 
$\overline{\text { Zeller, E. (2002). Essay on the history of Greek philosophy. (S. Frank, Transl.). }}$ Moscow: Kanon + ROOI Rehabilitation. [In Russian].

Shichalin, Yu. A. (2000). History of ancient Platonism. In the institutional aspect. Moscow: GLK. [In Russian].

Steiner, R. (2015). On the technique of thinking: eight lectures 1908-1909. (G.. Kavataradze, Transl.). St. Petersburg: Keys. [In Russian].

Eliade, M. (2009). History of Faith and Religious Ideas: From Gautama Buddha to the Triumph of Christianity. Moscow: Academic Project. [In Russian].

Jaspers, K. (2021). Great philosophers. Book III. Those thinking from the source of metaphysics. (A. Sudakov, Transl.). Moscow: Canon + ROOI "Rehabilitation". [In Russian].

\section{Volodymyr Bilodid}

Candidate of Philosophical Sciences (Ph.D.), Senior Researcher, Skovoroda Institute of Philosophy National Academy of Sciences of Ukraine; Kyiv, Ukraine; e-mail:bilodid.vd@gmail.com; ORCID: htpps//orcid.org/0000-00033097-962X

\section{Platonism and Aristotelianism as a source of the differences between internal forms of Western European and Byzantine christian traditions in the Middle Ages}

\section{Abstract}

The article examines the peculiarities of the attitude to Greek philosophy in Western Europe and Byzantium in the context of the historical development of the polarity of mentalities and cultures of Ancient Greece and Ancient Rome. On the one hand, the philosophical teachings of Plato/Plotinus and on the other-Aristotle. It is shown that these polarities in their transformed versions manifested themselves in the division of medieval Europe into the Christian East (Greek-speaking and «Greek-minded» Byzantium) as the direct heir of Greek culture, and into the Christian West, as the direct heir of Latin culture. The adoption of Christianity both in the East and the West through «filters» of different mentalities and cultures along with other historical factors, led to the division of Christianity into Orthodoxy (the «Greek» Church) and Catholicism (the «Latin» Church). It is argued that Latin patristics organically grew in the 
West into the dominance of scholasticism, which was not the case in the Christian East, where the full formation of scholasticism was blocked and it remained in its infancy in a state of protoscholasticism. It is asserted that the Roman Catholic West of the scholastic era (9-14th centuries), based on both Platonism and Aristotelianism, inherits Epistemic-Aristotelian type of philosophizing as a paradigmatic for its theology and philosophy, whereas the Orthodox East, despite all its oscillations, maintains dominant in antiquity, Platonic line of philosophizing as a paradigmatic for its spiritual culture. Through Aristotle, as the "father" and "First-Philosopher» of scolasticism, Christian Aristotelianism has intensively grown and incorporated itself in the culture of Western Europeans and their mentality. The transformation of Aristotelianism into the «inner form of Western civilization" happened (S. Averintsev).

Keywords: Byzantium, Platonism, Aristotelianism, scholasticism, Sophian philosophizing, epistemic philosophizing, Orthodoxy, Catholicism. 